\title{
Evaluation of Biopolimeric Films of Cassava Starch with Incorporation of Clay Modified by Ionic Exchange and its Application as a Coating in a Fruit
}

\author{
Victor Rafael Leal Oliveira ${ }^{a *}$, Tálisson Davi Noberto Xaviera, Nicolas Oliveira Araújo ${ }^{a}$, José Gustavo
}

Lima Almeida ${ }^{a}$, Edna Maria Mendes Aroucha ${ }^{a}$, Francisco Klebson Gomes Santos ${ }^{a}$, Ricardo Henrique

de Lima Leite ${ }^{a}$, Karyn Nathallye de Oliveira Silva ${ }^{b}$

\author{
${ }^{a}$ Universidade Federal Rural do Semi-Arido - UFERSA, 59.600-000, Mossoró, RN, Brazil \\ ${ }^{b}$ Universidade Federal do Rio Grande do Norte- UFRN, 59.078-970, Natal, RN, Brazil
}

Received: December 06, 2016; Revised: October 17, 2017; Accepted: December 04, 2017

\begin{abstract}
Coatings technologies with biopolymeric films are effective in maintaining the chemical and sensory characteristics of several fruits. Cassava starch is an attractive biopolymeric because of its renewable characteristics and low cost, but it has a high transfer rate of water vapor. Hydrophilic compounds of organically modified montmorillonite clay by ion exchange can be used to improve the limiting properties of starch in exchange for additives such as lipids. The solutions prepared with $5 \% \mathrm{~m} / \mathrm{v}$ starch $/ 5 \% \mathrm{~m} / \mathrm{m}$ cationic / anionic clay and uncoated were applied in caja fruit, harvested at physiological maturity, selected for absence of defects and color uniformity. The experimental design was performed with four storage times ( $0,3,6$ and 9 days). For the maturation index, there was an isolated effect of the type of coating and storage time, showing the composite films of modified cationic clay with greater MI of the fruits in comparison to the control fruits.
\end{abstract}

Keywords: Biopolymeric films, cassava starch, ion exchange, caja fruit, maturation index.

\section{Introduction}

Edible films and/or biopolymeric are potentially known to reduce weight loss and humidity, improve respiration rate, maintain firmness and color characteristic of foods, retain, among other things, soluble solids, sugars and acidity, in addition to protecting the mechanical and maintaining them as fresh as possible ${ }^{1}$.

Cassava starch is an attractive biopolymer due to its renewable, abundant and low cost characteristics, but it has limitations in the formation of films, such as high solubility in water, high transfer of water vapor, and low mechanical resistance. Hydrophilic composites of montmorillonite clay organically modified can be used as compatibilizing agents in the polymer network in order to improve the limiting properties of cassava starch in exchange for commonly used additives, such as lipids, which may negatively affect the properties of films ${ }^{2}$.

The use of these coatings raises the maturation index (MI), which can be evaluated as the result of the alteration in the quantities of organic acids and sugar with changes that make possible the increase of sweetness, widely used in the food industry as a parameter associated to the degree of maturation and flavor reference for fruit, thus it is considered one of the indicators of the increase of the useful life, which consequently maintains the good characteristics in the fruits; the caja fruit, for example, is in constant process of expansion and of high commercialization. Its cultivation already covers

*e-mail: vrafaeloliveira@uol.com.b several areas of the North and Northeast regions, however, they are quite perishable, and there is a growing need to increase the useful life, maintaining the characteristics of acceptability $^{3,4,5}$.

In order to control the negative effects of lipid addition and increase the MI of the caja fruit, this work has the objective of evaluating the use of montmorillonite clay, organically modified with ion exchange, in addition to the biopolymeric matrix constituted of cassava starch, in maturation of caja fruit over nine days of storage.

\section{Materials and Methods}

\subsection{Materials}

The cassava starch of the Indústria Primícias do Brasil, Macaíba, Rio Grande do Norte, Brazil, was used in the preparation of the films. Glycerol PA (Synth) was used as plasticizer. Sodium bentonite clay, supplied by Armil Mineração Nordeste (AMN), Parelhas, Rio Grande do Norte, Brazil, with light cream color, in powder form, with a mean particle size of $0.074 \mathrm{~mm}$ and a cation exchange capacity of $75 \mathrm{meq} / 100 \mathrm{~g}$.

The cation exchange was carried out in the presence of cetyltrimethyl ammonium bromide, manufactured by Sigma Life Science/USA, with 98\% purity, ethyl alcohol $\left(95.5^{\circ} \mathrm{GL}\right.$ Absolute), brand Synth. The anion exchange was done in the presence of sodium dodecyl sulfate (SDS), manufactured 
by Inlab Confiança, and ethylene glycol, manufactured by Merck, with a molar mass of $62.07 \mathrm{~g} / \mathrm{mol}$ and $99.5 \%$ purity.

The caja fruit (Spondias mombin L.) was taken from the university's own orchard (UFERSA).

\subsection{Ionic exchange}

In the anion exchange, $1 \mathrm{~g}$ of clay was diluted in $80 \mathrm{ml}$ of ethylene glycol. Then $1 \mathrm{~g}$ of sodium dodecyl sulfate (SDS) was added to $20 \mathrm{ml}$ of distilled water. The mixtures were vigorously stirred for 2 hours at $100^{\circ} \mathrm{C}$. After stirring, the mixture was filtered and washed to remove excess of salt. The final product was dried in oven at $105^{\circ} \mathrm{C}^{6}$.

In the cation exchange, $1 \mathrm{~g}$ of clay was diluted in $100 \mathrm{~mL}$ of distilled water, with constant agitation at $30^{\circ} \mathrm{C}$. In another container, cetremide or cetyltrimethyl ammonium bromide (CTAB) was added in $20 \mathrm{~mL}$ of $0.06 \mathrm{M}$ ethyl alcohol. The mixtures were vigorously stirred at $30^{\circ} \mathrm{C}$ for $12 \mathrm{~h}$. After stirring, the mixture was filtered and washed to remove excess of salt. The final product was dried in oven at $105^{\circ} \mathrm{C}^{7}$.

\subsection{Preparation of the filmogenic solution}

The film-forming solutions were prepared according to the modified methodology of Cyras et $\mathrm{al}^{8}$, by adding $5 \mathrm{~g}$ of cassava starch with $20 \% \mathrm{w} / \mathrm{w}$ of glycerol in relation to the dry mass of the biopolymer with heating up to $70^{\circ} \mathrm{C}$ for 15 minutes in complete homogenization. Then, two different blends dispersed in distilled water were prepared: $5 \% \mathrm{w} / \mathrm{w}$ anionic clay and $5 \% \mathrm{w} / \mathrm{w}$ cationic clay in relation to the dry mass of the polymer. The concentrations of clay were previously tested in the preparation of films with polymeric matrix of cassava starch in varied concentrations following the indication of several authors Li \& $\mathrm{Guo}^{6}$; Monteiro et $\mathrm{al}^{9}$; Romero-Bastida et $\mathrm{al}^{10}$. Preliminary results are not showed.

Finally, the solutions prepared were mixed and placed in an ultrasonic bath for 30 minutes to facilitate dissolution. The filmogenic solutions were arranged in rectangular plates and dried at $40^{\circ} \mathrm{C}$ for 6 hours in the oven by the casting method.

\subsection{Characterization of Clay}

\subsubsection{X-ray diffraction - XRD}

The XRD analyzes were conducted at room temperature on a Shimadzu DRX-6000 equipment, using Cuk $\alpha$ radiation $(\lambda=1.5418 \AA)$, a voltage of $40 \mathrm{kV}$ and a current of $30 \mathrm{~mA}$. The samples were analyzed in a range of $2 \theta$ between 2 and $30^{\circ}$ with a scan speed of $2^{\circ} / \mathrm{min}$.

\subsubsection{Fourier transform by infrared spectroscopy - FTIR}

The infrared absorption spectra were obtained with a Shimadzu IRTracer-100 spectrometer, scanning from 7800 to $350 \mathrm{~cm}^{-1}$ and $4 \mathrm{~cm}^{-1}$ resolution. The samples were characterized directly by attenuated total reflectance, without any type of preparation.

\subsection{Characterization of biopolymeric films}

\subsubsection{Thickness}

The thicknesses of the films were measured using a Mitutoyo micrometer (Model MDC-25M, MFG / Japan). The measurements were taken at five different points throughout the film.

\subsubsection{Scanning electronic microcopy - SEM}

The samples were submitted to the SEM (model VEGA 3 TM, TESCAN-Czech Republic, 2013) applied at a voltage of $15 \mathrm{kV}$, with a magnitude of $1 \mathrm{kx}$.

\subsubsection{Water vapor permeability - WVP}

The water vapor permeability of the films was determined gravimetrically, according to the standard ASTM method E96-95 ${ }^{11}$ and Maran et $\mathrm{l}^{12}$. The films were cut into square pieces $(2 \mathrm{~cm} \times 2 \mathrm{~cm})$ and sequentially deposited on top of the WVP measuring cells. The water level was up to $1 \mathrm{~cm}$ below the film. The weight of each cell was measured before being deposited in a desiccator which contained silica stones at the bottom, as well as a relative humidity of $60 \%$ and internal temperature of $28^{\circ} \mathrm{C}$. Cell weight was measured every hour over a period of 8 hours. The WVP of the films was calculated in g.mm/kPa.m $\mathrm{m}^{2} . \mathrm{h}$ as follows in Equation 1:

$$
W V P=\frac{W \cdot L}{A . t . \Delta P}
$$

Where $\mathrm{W}$ is the weight of water permeating through the film $(\mathrm{g}) ; \mathrm{L}$ is the film thickness $(\mathrm{mm})$; $\mathrm{A}$ is the permeation area $\left(\mathrm{m}^{2}\right) ; \mathrm{t}$ is the permeation time $(\mathrm{h}) ; \Delta \mathrm{P}$ is the pressure difference to water vapor between the two sides of the film (KPa).

\subsubsection{Solubility}

For solubility, the methodology adapted from Casariego et $\mathrm{al}^{13}$ was used. Film disks with $2 \mathrm{~cm}$ of diameters were dried at $105^{\circ} \mathrm{C}$ for 1 hour. The disks were immersed in distilled water at room temperature, shaken for 24 hours. Then they were dried again at $105^{\circ} \mathrm{C}$ for $1 \mathrm{~h}$. The solubility was calculated from Equation 2:

$$
S=\frac{m i-m f}{m i} \times 100
$$

Where $\mathrm{S}$ is the solubility (\%); $\mathrm{m}_{\mathrm{i}}$ is the initial mass $(\mathrm{g})$; $\mathrm{m}_{\mathrm{f}}$ is the final mass $(\mathrm{g})$.

\subsubsection{Opacity}

The opacity of the films was determined by the methodology adapted from Fakhouri et $\mathrm{al}^{14}$ with the colorimeter (model CR 10, Minolta), calibrated with a standard white background and a standard black background. The opacity values were calculated according to Equation 3: 


$$
\mathrm{Op}=\frac{O p_{B}}{O p_{W}} \times 100
$$

Where $\mathrm{Op}_{\mathrm{B}}$ is the opacity of the film against a black background; $\mathrm{Op}_{\mathrm{w}}$ is the opacity of the film against a white background.

\subsubsection{Mechanical properties}

The mechanical properties were determined using an Testing Machine (model DL5000/10000, Paraná, Brazil), which operates according to standard ASTM method D882-83 ${ }^{15}$ at a test speed of $5 \mathrm{~mm} / \mathrm{min}$ with application of total force of $5 \mathrm{kN}$. The samples follow the same standard and are evaluated with length of $50 \mathrm{~mm}$, width of $5 \mathrm{~mm}$ and maximum thickness of $0.25 \mathrm{~mm}$.

\subsection{Characterization of Caja Fruit}

The caja fruit was collected at the ideal physiological maturity, previously selected for absence of defects and color uniformity. The fruits were divided into three lots and three treatments, control (uncoated), and coated. The coatings were then applied to the caja fruit by the dipping technique and subsequently maintained at $15^{\circ} \mathrm{C} \pm 2^{\circ} \mathrm{C}$ and $90 \% \pm 2 \% \mathrm{RH}$ for nine days.

The mass loss was considered by the difference of the initial weight and the final weight in the storage time ${ }^{16}$. The weighing was performed in analytical balance Marte (Model AY220, Minas Gerais, Brazil). In the determination of color, a Konica Minolta colorimeter (COLOR READ CR10, Japan) was used, the readings were expressed in index $C$, chromaticity $\mathrm{a}^{*}$ and $\mathrm{b}^{*}$. The measurements were determined in three equidistant points, considering the average of the three readings.

\subsection{Statistical analysis}

In the biopolymeric films, a completely randomized design with two treatments and three replicates was used. The significant difference between the means was established by the Tukey test at $5 \%$ probability of error with the smallest minimum difference for the multiple comparisons.

The statistical design used in the storage of the fruits was completely randomized in subdivided portions with three treatments: control, anionic and cationic, with three storage times $(3,6$, and 9 days), with three replicates of six fruits for each treatment and storage period. The data were submitted to analysis of variance with the aid of SISVAR software. A significant effect of the interaction between the factors under analysis was observed, and the means were compared using Tukey's test at 5\% of probability.

\section{Results and Discussion}

\subsection{Ionic Exchanges}

\subsubsection{FTIR}

Figures $1 \mathrm{~A}$ and $1 \mathrm{~B}$ show the infrared spectra of the BT clay in its sodium form and after cation and anion exchange, respectively.

In Figure $1 \mathrm{~A}$ it is possible to evaluate some changes between the two spectra and to observe that there was overlap in several regions between the transmittance bands of the two samples at the same frequency. This fact is related to the octahedral structure of bentonite, which is formed by elemental crystals of aluminum or silicon in the center and oxygen and hydroxyls at the vertices between two leafs of tetrahedrons ${ }^{7,17}$.

In the region of high transmittance, in the peaks between $2845 \mathrm{~cm}^{-1}$ and $2925 \mathrm{~cm}^{-1}$, there are the presence of the bands corresponding to the organic groups associated to the $-\mathrm{CH}$ and the cations of $\mathrm{Al}^{3+}$, proving the ion exchange done in the BT clay by cationic surfactant. The peak near $1500 \mathrm{~cm}^{-1}$ proves the presence of bands that correspond to the functional groups of the quaternary ammonium salt $-\mathrm{CH}$ and $-\mathrm{CN}$, and the region of transmittance at $1480 \mathrm{~cm}^{-1}$ indicates groups associated to the $-\mathrm{CN}$ and the presence of elements such as $\mathrm{Si}^{2+}$ cation and oxygen of the tetrahedral leaf; bands smaller than $1000 \mathrm{~cm}^{-1}$ were displaced to smaller values due to the presence of the hydroxyl at the vertices of the tetrahedral layer ${ }^{7,18}$. Similar results were presented by Marcel et $\mathrm{al}^{19}$ and Sara et $\mathrm{al}^{20}$.

In Figure $1 \mathrm{~B}$ the spectra are formed between the characteristic peaks of $640 \mathrm{~cm}^{-1}$, in addition to those, in points near $700 \mathrm{~cm}^{-1}$. These characteristic peaks undergo a displacement, approaching $942 \mathrm{~cm}^{-1}$ and $1008 \mathrm{~cm}$ ${ }^{-1}$, which corresponds to the electrostatic interactions between the silica, oxygen and aluminum bonds, which according to Sarier et $\mathrm{al}^{21}$ this is due to fact that there is an intercalation of the MMT, forming sensitive bands in higher wave numbers.

These results confirm the hypothesis of anion exchange when it presents nanocomposites of starch and modified clay with a greater amount of hydrogen bonds established by the lower presence of free hydroxyl groups in relation to the unmodified clay, showing the electrostatic affinity of the functional groups of the surfactant with the structure of cassava $\operatorname{starch}^{22}$. Similar results were reported by Chiu et $\mathrm{al}^{23}$ and Monteiro et $\mathrm{al}^{10}$. 


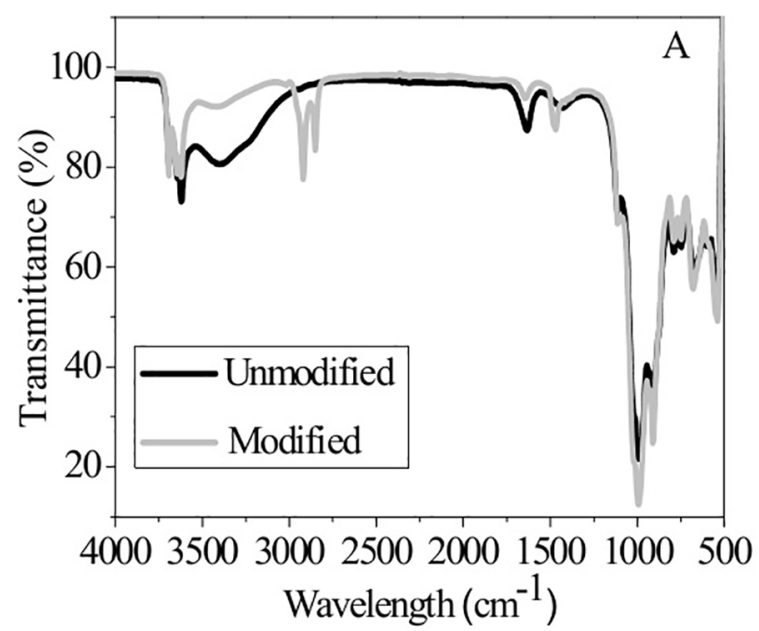

Figure 1. FTIR A) Unmodified clay overlapped with Cationic clay; B) Unmodified clay overlapped with anionic clay.

\subsubsection{XRD}

Figures $2 \mathrm{~A}$ and $2 \mathrm{~B}$ show the results of $\mathrm{X}$-ray diffraction, of the BT clay in its sodium form and after cation and anion exchange, respectively.

In Figure 2A, the BT clay modified by cationic surfactant showed a characteristic displacement to lower values at $2 \theta$, close to $5.5^{\circ}$, compared to the natural BT clay, at $6.5^{\circ}$, due to the influence of the functional groups on the contact surface between the layers of silicate, indicating an increase of the spaces between layers, even though, at the same time, they demonstrate a slight vulnerability of the polymer matrix when associating with the clay, not reaching a complete exfoliation, due mainly to the big interactions between the hydroxyl groups present in the chains, with a significant increase of the spaces between layers of $\mathrm{BT}$ and $\mathrm{BT} / \mathrm{CT}^{6,24}$. Data obtained in

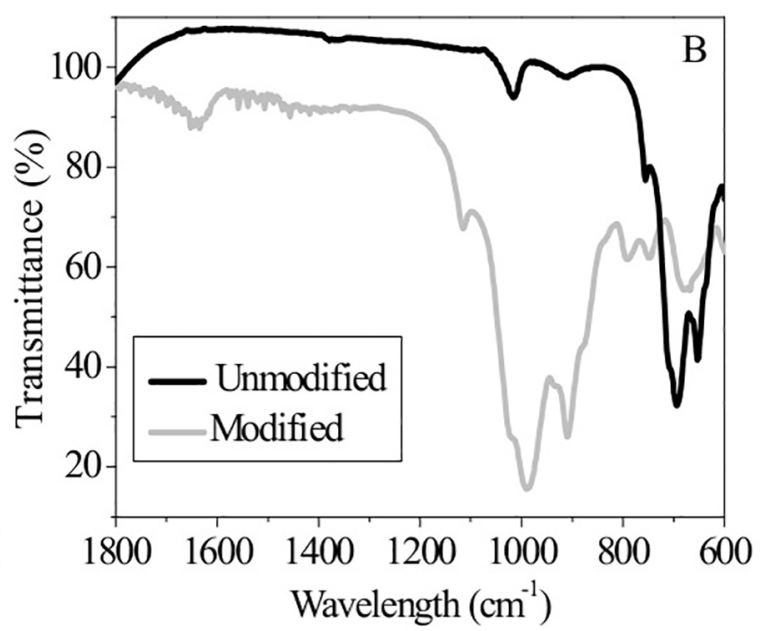

other studies present similar results (Romero-Bastida et $\mathrm{al}^{11}$ and Alboofetileh et $\mathrm{al}^{24}$ ).

Figure $2 \mathrm{~B}$ shows a particular characteristic of $2 \theta$ marked peaks, approximately $26.6^{\circ}$, when it overlaps with BT clay modified by anionic surfactant, confirming the increase of the basal space and the consequent increase of the region between layers when compared to the natural BT clay, displayed in $2 \theta$, approximately $26.8^{\circ}$.

According to Hua ${ }^{25}$ and Moyo et $\mathrm{al}^{26}$, this displacement in Figure $2 \mathrm{~B}$ is associated to the vulnerability of the polymer matrix as to its intercalation between the layers of clay modified due to the presence of the salt, compatible with the polarity of the polymer structure, demonstrating accentuated characteristics in the diffraction peaks in these points. The peaks have high intensity and stable basal line, indicating a moderate crystal phase and regular structure with significant distancing and optimum aggregation between the clay and the surfactant.
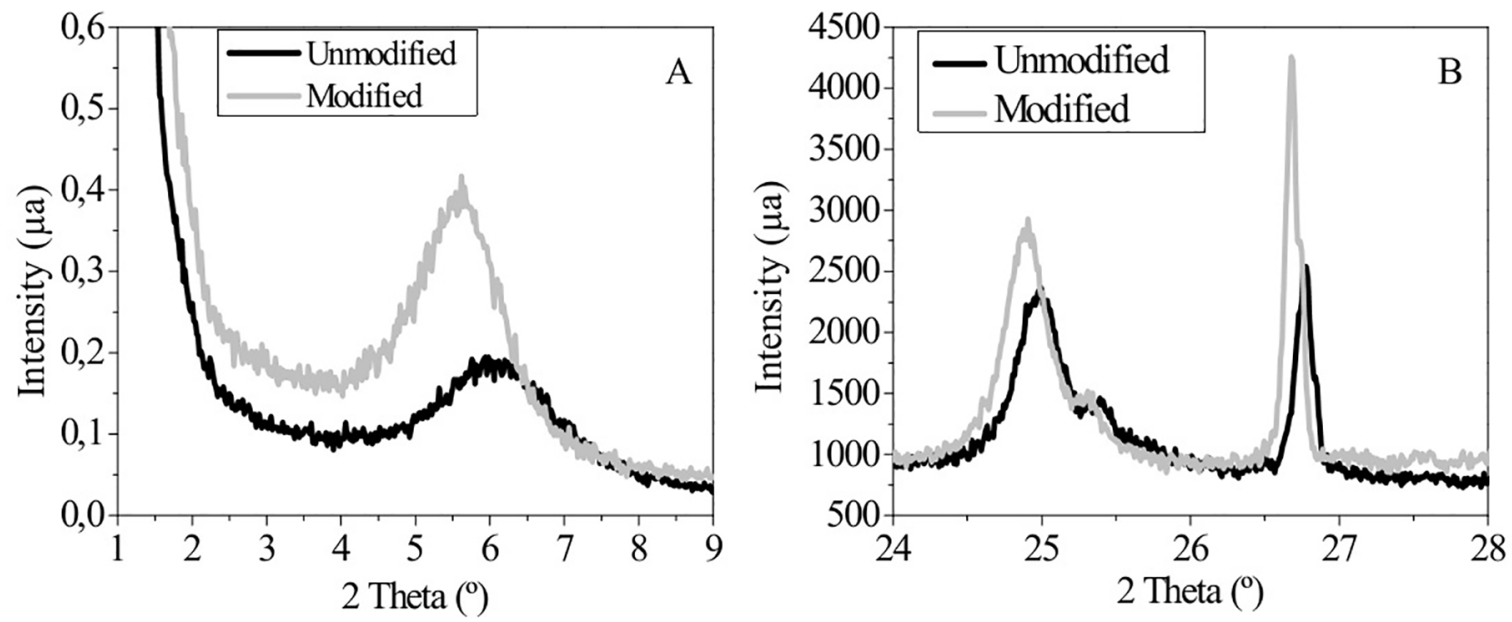

Figure 2. XRD A) Unmodified clay overlapped with cationic clay; B) Unmodified clay overlapped with anionic clay. 


\subsection{Biopolymeric films}

\subsubsection{SEM (Scanning Electron Microscopy)}

In Figure 3 it is possible to evaluate the micrographs for the obtained biofilms.

Observing the Figure 3 it is possible to visualize the pattern of arrangement of the silicate layers on the surface of the biofilms before and after the ionic exchanges. In general, there is a clear formation and smooth morphology of the polymeric matrix of the biofilms in the presence of clay with ionic exchange, proving the adjustment of the polymer network with the incorporation of the modified clay, and also, showing good interaction between all the components, forming a very homogeneous mixture ${ }^{27}$.
In Figure 3A, it is observed that the polymer network is disorganized with a more accentuated accumulation of unhomogenized natural clay, which, according to Casariego ${ }^{13}$; $\mathrm{Zhu}^{28}$ and Tjong ${ }^{29}$ are due to the fact that the starch-natural clay nanocomposites have little affinity between the structures, allowing the silicate layers to be stacked, which decreases the interaction forming an intercalated and brittle nanocomposite, showing a less favorable behavior of natural clay with starch.

In Figure $3 \mathrm{~B}$ and $3 \mathrm{C}$, the compounds of starch with modified clay, in both cases, presented better agglomerations forming a cohesive polymer matrix, which, according to Veiga-Santos et $\mathrm{al}^{30}$ and Tan $\&$ Thomas $^{31}$, is due to the organic modification of the clay through functional groups of the surfactants used, which are electrostatically compatible with the molecules of the starch, allowing the wide penetration of
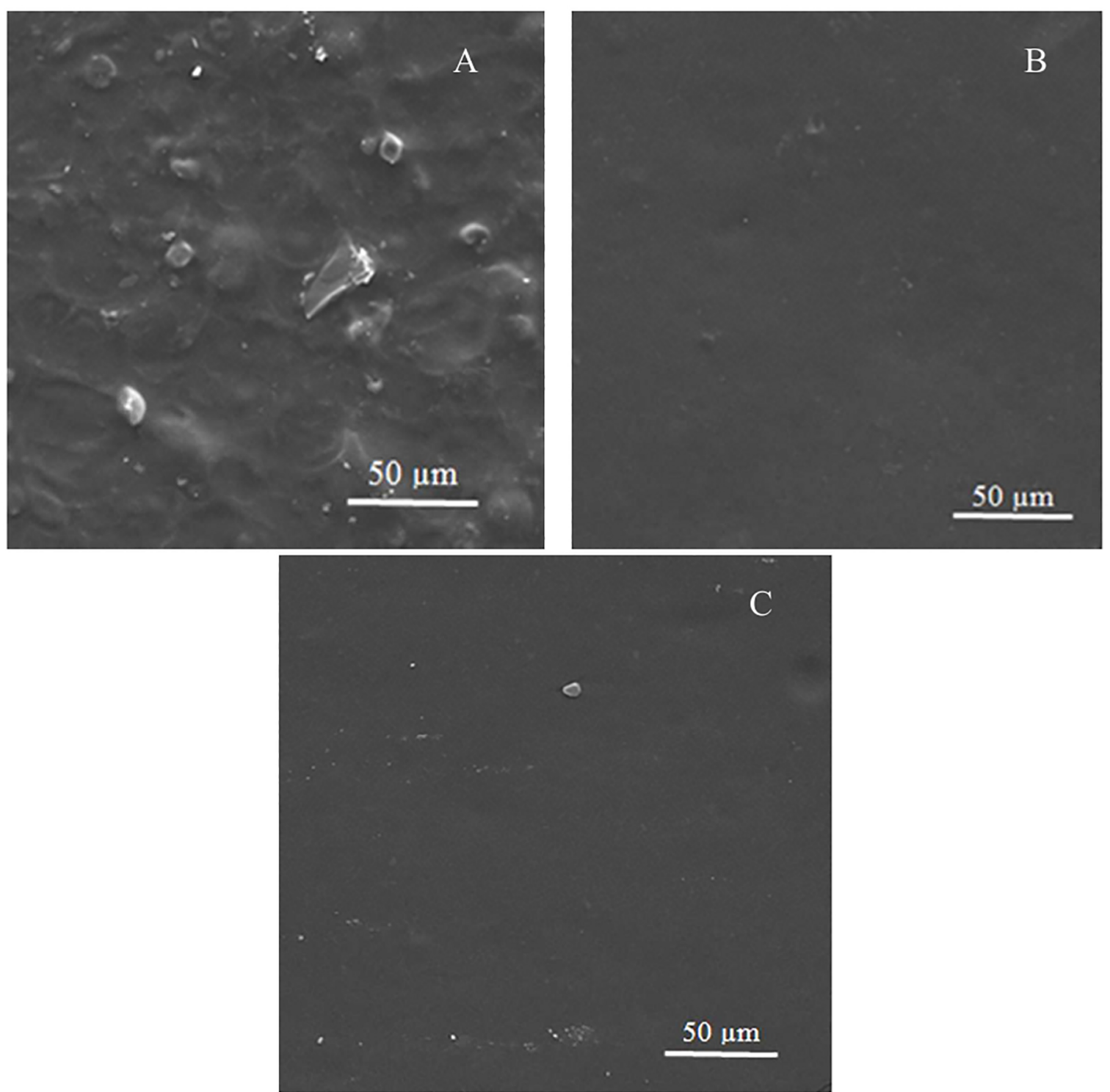

Figure 3. SEM A) Cassava starch biofilm with unmodified clay B) Cassava starch biofilm with cationic clay C) Cassava starch biofilm with anionic clay. Magnitude $1 \mathrm{kx}$. 
the biopolymer between the layers of silicate, characterizing the formation of a exfoliated nanocomposite.

\subsubsection{WVP, Solubility, Opacity and Mechanical Properties}

The thickness of the films obtained in this study ranged from $0.14 \mathrm{~mm}$ to $0.16 \mathrm{~mm}$, and did not present statistical difference $(p<0.05)$ between treatments.

The results of WVP, solubility, opacity and mechanical properties of the biopolymeric films are shown in Table 1.

As shown in Table 1, the decrease of the WVP values of natural BT clay and BT clay with treatment was satisfactorily decreased with statistical difference $(p<0.05)$ between the three treatments, with emphasis on the cation exchange treated films, which showed lower WVP results than films treated with anion exchange.

According to the studies of Kavoosi, Dadfar \& Purfard 32 and Acosta et $\mathrm{al}^{33}$ these results of WVP are explained by the fact of the better organization of the components of the mixture, which benefit the polymer adjustment, facilitating the increase of the contact area, observed in Figure 2, when a greater basal space in the clay structure with cationic treatment, evident in the greater distancing of the peaks of equivalence in this clay, which are larger than the distance of peaks of the clay with anion treatment, leading to a lengthening in the route of the water vapor molecules along of the film.
Solubility showed an opposite aspect to WVP. The anionic treatment caused the maximum reduction, about $45 \%$ in relation to the untreated clay film, possibly due to the $\mathrm{NH}_{2}$-MMT amino groups type, which made the films more hydrophobic or more hydrophilic, according to the amount disposed in each quaternary salt. A larger number of these groups affects decreasing the solubility ${ }^{34}$.

The studies of $\mathrm{Mu}$ et $\mathrm{al}^{35}$ presented similar results and pointed out that the more hydrophilic nature of the unmodified BT clay than the modified BT clay acts as a barrier between the starch and the solvent when analyzing the basal space and the increase of the modified area by the quaternary salt in both cases. Thus, the use of unmodified clay interferes with an increase in solubility.

The opacity of the films of natural or modified (cationic and anionic) clay did not differ statistically $(p<0.05)$ between them. Other authors such as Cyras et $\mathrm{al}^{8}$ and Monteiro et $\mathrm{al}^{10}$ evaluated the use of biofilms with a polymeric matrix constituted only of cassava starch and obtained values similar to those found in this study. It is possible to infer that the addition of natural or modified clay did not give the biofilms a more opaque appearance and could be considered transparent when compared to cassava starch coatings on fruits.

The control film, with untreated clay, presented lower tensile strength, while the treated films showed an increase, with a statistical difference $(p<0.05)$ between the three

Table 1. WVP, solubility, opacity and mechanical properties of the films.

\begin{tabular}{cccccc}
\hline Film & $\begin{array}{c}\text { WVP }\left(\mathrm{x} 10^{-2} \mathrm{~g} \cdot \mathrm{s}^{-}\right. \\
\left.{ }^{1} \cdot \mathrm{m}^{-1} \cdot \mathrm{Pa}^{-1}\right)\end{array}$ & Solubility $(\%)$ & Opacity (\%) & $\begin{array}{c}\text { Tensile Ttrength } \\
(\mathrm{MPa})\end{array}$ & $\begin{array}{c}\text { Elongation at break } \\
(\%)\end{array}$ \\
\hline Control & $4.18 \pm 0.02^{\mathrm{a}}$ & $66.15 \pm 0.15^{\mathrm{a}}$ & $45.47 \pm 1.09^{\mathrm{a}}$ & $0.74 \pm 0.02^{\mathrm{c}}$ & $31.59 \pm 0.14^{\mathrm{a}}$ \\
Cationic & $2.52 \pm 0.01^{\mathrm{c}}$ & $42.10 \pm 0.24^{\mathrm{b}}$ & $46.16 \pm 1.06^{\mathrm{a}}$ & $0.88 \pm 0.02^{\mathrm{b}}$ & $20.76 \pm 0.12^{\mathrm{b}}$ \\
Anionic & $2.98 \pm 0.02^{\mathrm{b}}$ & $36.31 \pm 0.04^{\mathrm{c}}$ & $43.49 \pm 1.06^{\mathrm{a}}$ & $1.43 \pm 0.08^{\mathrm{a}}$ & $17.49 \pm 0.11^{\mathrm{c}}$ \\
\hline
\end{tabular}

CAT: Clay with cationic treatment; ANI: Clay with anionic treatment. Different letters in each column indicate the statistical difference $(\mathrm{p}<0.05)$ between treatments.

Table 2. Mass loss (\%) of the caja fruit.

\begin{tabular}{cccc}
\hline \multirow{2}{*}{ Treatment } & \multicolumn{3}{c}{ Storage Days } \\
\cline { 2 - 4 } & 3 & 6 & $7.45 \pm 0.02^{\mathrm{a}}$ \\
\hline Control & $6.50 \pm 0.06^{\mathrm{a}}$ & $6.94 \pm 0.03^{\mathrm{a}}$ & $6.07 \pm 0.03^{\mathrm{c}}$ \\
Cationic & $4.85 \pm 0.02^{\mathrm{c}}$ & $5.74 \pm 0.03^{\mathrm{c}}$ & $7.01 \pm 0.01^{\mathrm{b}}$ \\
Anionic & $5.14 \pm 0.01^{\mathrm{b}}$ & $6.63 \pm 0.02^{\mathrm{b}}$ & \\
\hline
\end{tabular}

Different letters in each column indicate the statistical difference $(\mathrm{p}<0.05)$ between treatments.

Table 3. Parameters $a^{*}, b^{*}$ and chroma index for the color of the caja fruit.

\begin{tabular}{|c|c|c|c|c|c|c|c|c|c|}
\hline \multirow{3}{*}{ Treatment } & \multicolumn{9}{|c|}{ Days of Storage } \\
\hline & \multicolumn{3}{|c|}{3} & \multicolumn{3}{|c|}{6} & \multicolumn{3}{|c|}{9} \\
\hline & $a^{*}$ & $b^{*}$ & $\mathrm{c}^{*}$ & $a^{*}$ & $b^{*}$ & $\mathrm{c}^{*}$ & $a^{*}$ & $b^{*}$ & $\mathrm{c}^{*}$ \\
\hline Control & $-8.6^{\mathrm{cA}}$ & $48.9^{\mathrm{bA}}$ & $49.6^{\mathrm{bcA}}$ & $-0.2^{\mathrm{bA}}$ & $50.7^{\mathrm{abA}}$ & $50.7^{\mathrm{bcA}}$ & $6.0^{\mathrm{aA}}$ & $52.7^{\mathrm{aA}}$ & $53.0^{\mathrm{aA}}$ \\
\hline Cationic & $-12.4^{\mathrm{cC}}$ & $44.0^{\mathrm{bcBC}}$ & $45.7^{\mathrm{bcBC}}$ & $-7.6^{\mathrm{bB}}$ & $44.2^{\mathrm{bcBC}}$ & $45.8^{\mathrm{bcBC}}$ & $-1.7^{\mathrm{aBC}}$ & $47.1^{\mathrm{aBC}}$ & $47.2^{\mathrm{aBC}}$ \\
\hline Anionic & $-11.3^{\mathrm{cBC}}$ & $43.3^{\mathrm{abBC}}$ & $44.8^{\mathrm{bcBC}}$ & $-7.0^{\mathrm{bBC}}$ & $45.0^{\mathrm{bcBC}}$ & $45.6^{\mathrm{bcBC}}$ & $-1.5^{\mathrm{aBC}}$ & $48.4^{\mathrm{aBC}}$ & $48.4^{\mathrm{aBC}}$ \\
\hline
\end{tabular}

*Different lowercase letters in each parameter indicate the statistical difference $(\mathrm{p}<0.05)$ for the storage time. ${ }^{*}$ Different capital letters compare in the column in each parameter, and indicate the statistical difference $(p<0.05)$ for the type of coating. 
treatments, and with emphasis for the films treated with anion exchange, which presented higher resistance, reinforcing the study of other authors, such as Chen \& Evans ${ }^{36}$ and Cyras et $\mathrm{al}^{37}$, which point to increased stiffness of the material when added MMT clay in cassava starch films.

According to Rometo-Bastida ${ }^{11}$ these results are due to the exfoliated structure obtained by the addition of modified clay in the polymer matrix, which benefit the transport of the tension applied by the better dispersion of the reinforcing elements.

The elongation at break has an opposite effect, when there is an increase of tensile strength and stiffness of the films, there is a reduction of the elastic properties, observed with the decrease of this parameter of elongation in films with anion exchange. Similar results were obtained by Romero-Bastida et $\mathrm{al}^{11}$ and Farahnaky et $\mathrm{al}^{38}$. This can be attributed to the fact that the filling materials decrease the deformation of the polymer structure due to the formation of a layer of immobilizing biopolymer at the polymer-filling material interface and reduce the flexibility of the smooth surface of $\operatorname{starch}^{39}$.

\subsection{Properties of Caja Fruit}

\subsubsection{Mass loss}

In Table 2, it is possible to evaluate the mass loss of the caja fruit during the period of storage.

At the end of the nine days of storage, the fruits coated with the coverage of the cationic treatment had a much lower mass loss $(6.07 \%)$ to the fruits conditioned with the coverage of the anion treatment $(7.01 \%)$ and control fruits $(7.45 \%)$, with statistical difference $(p<0.05)$ among the three treatments throughout the storage time.

The results of Table 2 demonstrate that the loss of mass was satisfactory for the coatings used with treated clay in the polymer network, as they restricted the diffusion of water vapor, reducing, transpiration, loss of water throughout the days of treatment and consequent decrease of mass loss ${ }^{40,41}$.

According to the studies of Lee et $\mathrm{al}^{7}$ and Limchoowong et $\mathrm{al}^{42}$, the lower WVP presented in films with modified clay (Table 1) indicates that the polymer matrix with this composition has a low transfer of water vapor that ends up extending the transfer distance of the water molecules, thereby reducing the rate transfer of water.

\subsubsection{Color}

In Table 3, it is possible to evaluate the color of the caja fruit throughout the days of storage.

Changes in the color of the peel is a natural indicator of maturity. The change in the color of the peel, from green to yellow, is due to the degradation of chlorophyll and to the synthesis and development of carotenoids. Color is used to select many products in commercial classes and categories and is related to consumer perception of appearance ${ }^{43}$.
The values of the index $\mathrm{C}$, Chroma, is a representation of the appearance visible to the eyes of an infinity of colors, and, the greater, the more intense the observed color. Hence, an increase in $\mathrm{C}$ indicates a distance from the center of the coordinates of $\mathrm{C}$, where the colors are more vivid and strong, typical of yellowing. As seen in Table 3, the chroma index of the peel or the intensity of this color was influenced by the coating, being significant $(p<0.05)$ during the days of storage between the coated fruits and the control, and not significant for the coated fruits with ion exchange films. Chroma was also influenced by storage time from day 3 to day 9 .

Taking into consideration the treatments, the coated fruits presented chroma values inferior to the control fruits, evidencing that the color intensity is more accentuated in these fruits, that, predominantly, acquire the strong yellow color, typical of the maturation of the caja fruit throughout the period of storage ${ }^{44}$.

The values $a^{*}$ and $b^{*}$ represent the color itself; the values of $a^{*}$ vary from green when negative $\left(-a^{*}\right)$ to red when positive $\left(+a^{*}\right)$. The values of $b^{*}$ change from yellow when positive $\left(+b^{*}\right)$ to blue when negative $\left(-b^{*}\right)$, this indication proves the result of the Chroma index, as seen in Table 3 , showing significant changes in treatment time, and effect of coatings. Coated fruits showed significant differences $(p<0.05)$ between values of these with the control.

A peak in the production of ethylene may have caused the difference in the color of the peel in these fruits, since such a transformation is closely linked to the biosynthesis of this product, which is responsible for the increased activity of the enzymes chlorophyllases. These enzymes act by degrading chlorophyll, inducing the synthesis of enzymes from the maturation period, which produce carotenoids, in a marked way in the control fruits, confirming the satisfactory result of the application of the coating with treated clay ${ }^{45,46}$.

\section{Conclusion}

The incorporation of quaternary salts in clay modified its hydrophilic characteristics and altered the basal space of these, making satisfactory its use in the polymer matrix of cassava starch, which facilitated the increase of the contact area and a marked improvement in the barrier properties of the coatings used in caja fruits, resulting in a restriction on the diffusion of water vapor, which reduced the transpiration and loss of mass, consequently increasing the storage time and preserving the ideal characteristics of the fruit.

\section{References}

1. Galus S, Kadzi J. Food applications of emulsion-based edible films and coatings. Trends in Food Science \& Technology. 2015;45(2):273-283. 
2. Dadfar SMR, Ramezani A, Dadfar SMA. Investigation of oxygen barrier properties of organoclay/HDPE/EVA nanocomposite films prepared using a twostep solution method. Polymer Composites. 2009;30(6):812-819.

3. Mata MERMC, Duarte MEM, Zanini HLHT. Calor específico e densidade da polpa de cajá (spondias lutea L.) com diferentes concentrações de sólidos solúveis sob baixas temperaturas. Engenharia Agrícola. 2005;25(2):488-498.

4. Huang H, Jing G, Wang H, Duan X, Qu H, Jiang Y. The combined effects of phenylurea and gibberellins on quality maintenance and shelf life extension of banana fruit during storage. Scientia Horticulturae. 2014;167;36-42.

5. Soradech S, Nunthanid J, Limmatvapirat S, Luangtana-anan M. Utilization of shellac and gelatin composite film for coating to extend the shelf life of banana. Food Control. 2017;73(Pt B):1310-1317.

6. Li M, Guo Q. The preparation of the hydrotalcite-based composite phase change material. Applied Energy. 2015;156:207-212.

7. Lee SD, Park MS, Kim DW, Kim IL, Park DW. Catalytic performance of ion-exchanged montmorillonite with quaternary ammonium salts for the glycerolysis of urea. Catalysis Today. 2014;232:127-133.

8. Cyras VP, Manfredi LB, Ton-That MT, Vazquez A. Physical and mechanical properties of thermoplastic starch/montmorillonite nanocomposite films. Carbohydrate Polymers. 2008;73(1):5563.

9. Monteiro MKS, Oliveira VRL, Santos FKG, Leite RHL, Aroucha EMM, Silva RR, et al. Analysis of Water Barrier, Mechanical and Thermal Properties of Nanocoposites Based on Cassava Starch and Natural Clay or Modified by Anionic Exchange. Materials Research. 2017. In press.

10. Romero-Bastida CA, Tapia-Blácido DR, Méndez-Montealvo G, Bello-Pérez LA, Velázquez G, Alvarez-Ramirez J. Effect of amylose content and nanoclay incorporation order in physicochemical properties of starch/montmorillonite composites. Carbohydrate Polymers . 2016;152:351-360.

11. ASTM E96/E96M-12. (1993). Standard test methods for water vapour transmission of materials. Annual Book of Standards.

12. Maran JP, Sivakumar V, Sridhar R, Thirugnanasambandham K. Development of model for barrier and optical properties of tapioca starch based edible films. Carbohydrate Polymers. 2013;92(2):1335-1347.

13. Casariego A, Sousa BWS, Cerqueira MA, Teixeira J, Cruz L, Díaz R, et al. Chitosan/clay films' properties as affected by biopolymer and clay micro/nanoparticles' concentrations. Food Hydrocolloids. 2009;23(7):1895-1902.

14. Fakhouri FM, Martelli SM, Caon T, Velasco JI, Mei LHI. Edible films and coatings based on starch/gelatin: Film properties and effect of coatings on quality of refrigerated Red Crimson grapes. Postharvest Biology and Technology. 2015;109:57-64.

15. ASTM International. ASTM D882-12 - Standard Test Method for Tensile Properties of Thin Plastic Sheeting. West Conshohocken: ASTM International; 2012. Available from: $<\mathrm{http}: / / \mathrm{www}$.astm. org/Standards/D882>. Access in: 01/08/2016.
16. Pizato SC, Cortez-Vega WR, Prentice-Hernández C, Borges CD. Efeito da aplicação de diferentes revestimentos comestíveis na conservação de maçãs 'Royal Gala' minimamente processadas. Semina: Ciências Agrárias. 2013;34(1):235-264.

17. Kim NH, Malhotra SV, Xanthos M. Modification of cationic nanoclays with ionic liquids. Microporous Mesoporous Materials. 2006;96(1-3):29-35.

18. Ezquerro CS, Ric GI, Miñana CC, Bermejo JS. Characterization of montmorillonites modified with organic divalent phosphonium cations. Applied Clay Science. 2015;111:1-9.

19. Martins MG, Martins DOTA, Carvalho BLC, Mercante LA, Soriano S, Andruh M, et al. Synthesis and characterization of montmorillonite clay intercalated with molecular magnetic compounds. Journal of Solid State Chemistry. 2015;228:99-104.

20. Maisanaba S, Pichardo S, Puerto M, Gutiérrez-Praena D, Cameán AM, Jos A. Toxicological evaluation of clay minerals and derived nanocomposites: A review. Environmental Research. 2015;138:233-254.

21. Sarier N, Onder E, Ersoy S. The modification of Na-montmorillonite by salts of fatty acids: An easy intercalation process. Colloids and Surfaces A: Physicochemical and Engineering Aspects. 2010;371(1-3):40-49.

22. Kotal M, Bhowmick AK. Polymer nanocomposites from modified clays: Recent advances and challenges.Progress in Polymer Science. 2015;51:127-187.

23. Chiu CW, Huang TK, Wang YC, Alamani BG, Lin JJ. Intercalation strategies in clay/polymer hybrids.Progress in Polymer Science. 2014;39(3):443-485.

24. Alboofetileh M, Rezaei M, Hosseini H, Abdollahi M. Effect of montmorillonite clay and biopolymer concentration on the physical and mechanical properties of alginate nanocomposite films. Journal of Food Engineering. 2013;117(1):26-33.

25. Hua J. Synthesis and characterization of bentonite based inorganoorgano-composites and their performances for removing arsenic from water. Applied Clay Science. 2015;114:239-246.

26. Moyo L, Nhlapo N, Focke WW. A critical assessment of the methods for intercalating anionic surfactants in layered double hydroxides. Journal of Materials Science. 2008;43(18):61446158 .

27. Jiménez A, Fabra MJ, Talens P, Chiralt A. Effect of sodium caseinate on properties and ageing behaviour of corn starch based films. Food Hydrocolloids . 2012;29(2):265-271.

28. Zhu F. Composition, structure, physicochemical properties, and modifications of cassava starch. Carbohydrate Polymers. 2015;122:456-480.

29. Tjong SC. Structural and mechanical properties of polymer nanocomposites. Materials Science and Engineering: $R$ : Reports. 2006;53(3-4):73-197.

30. Veiga-Santos P, Suzuki CK, Nery KF, Cereda MP, Scamparini ARP. Evaluation of optical microscopy efficacy in evaluating cassava starch biofilms microstructure. LWT - Food Science and Technology. 2008;41(8):1506-1513.

31. Tan B, Thomas NL. A review of the water barrier properties of polymer/clay and polymer/graphene nanocomposites. Journal of Membrane Science. 2016;514:595-612. 
32. Kavoosi G, Dadfar SM, Purfard AM. Mechanical, physical, antioxidant, and antimicrobial properties of gelatin films incorporated with thymol for potential use as nano wound dressing. Journal of Food Science. 2013;78(2):E244-250.

33. Acosta S, Jiménez A, Cháfer M, González-Martínez C, Chiralt A. Physical properties and stability of starch-gelatin based films as affected by the addition of esters of fatty acids. Food Hydrocolloids . 2015;49:135-143.

34. Huang M, Yu J, Ma X, Jin P. High performance biodegradable thermoplastic starch-EMMT nanoplastics. Polymer. 2005;46(9):31573162 .

35. Mu C, Li X, Zhao Y, Zhang H, Wang L, Li D. Freezing/thawing effects on the exfoliation of montmorillonite in gelatin based bionanocomposite. Journal of Applied Polymer Science. 2013;128(5):3141-3148.

36. Chen B, Evans JRG. Thermoplastic starch-clay nanocomposites and their characteristics. Carbohydrate Polymers . 2005;61(4):455463.

37. Cyras VP, Tolosa Zenklusen MC, Vazquez A. Relationship between structure and properties of modified potato starch biodegradables films. Journal of Applied Polymer Science. 2006;101(6):4313-4319.

38. Farahnaky A, Dadfar SMM, Shahbazi M. Physical and mechanical properties of gelatin-clay nanocomposite. Journal of Food Engineering. 2014;122:78-83.
39. Matsuda DKM, Verceheze AES, Carvalho GM, Yamashita F, Mali S. Baked foams of cassava starch and organically modified nanoclays. Industrial Crops and Products. 2013;44:705-711.

40. Velickova E, Winkelhausen E, Kuzmanova S, Moldão-Martins $\mathrm{M}$, Alves VD. Characterization of multilayered and composite edible films from chitosan and beeswax. Food Science and Technology International. 2015;21(2):83-93.

41. Sousa e Silva JS, Finger FL, Correa PC. Armazenamento de frutas e hortaliças. In: Sousa e Silva J, ed. Secagem e armazenagem de produtos hortícolas. Viçosa: Aprenda Fácil; 2008.

42. Limchoowong N, Sricharoen P, Techawongstien S, Chanthai S. An iodine supplementation of tomato fruits coated with an edible film of the iodide-doped chitosan. Food Chemistry. 2016;200:223-229.

43. Chitarra MIF, Chitarra AB. Pós-colheita de frutas e hortaliças: fisiologia e manuseio. $2^{\mathrm{a}}$ ed. Lavras: UFLA; 2005.

44. Cavalcante LF, Lima EM, Freire JLO, Pereira WE, Costa APM, Cavalcanti IHL. Componentes qualitativos do cajá em sete municípios do brejo paraibano. Acta Scientiarum. Agronomy. 2009;31(4):627-632.

45. Santamaría Basulto F, Sauri Duch E, Espadas y Gil F, Diaz Plaza R, Larqué Saavedra A, Santamaría JM. Postharvest ripening and maturity indices for maradol papaya. Interciência. 2009;34(8):583-588.

46. Forato LA, Britto D, Rizzo JS, Gastaldi TA, Assis OBG. Effect of cashew gum-carboxymethylcellulose edible coatings in extending the shelf-life of fresh and cut guavas. Food Packaging and Shelf Life. 2015;5:68-74. 